\title{
GALL-STONES AND ANAESTHETICS
}

\author{
R. E. SNOW, M.B., B.CH., BAO., AND S. L. VANDEWATER, M.D., F.R.C.P.(c) ${ }^{*}$
}

THE THEORY that there is a causal relationship between diseases of the biliary tract and angina pectoris has been discussed since $1893,1,4,5,9,10,21,22,23,25,26$ It is thought to be caused by reflex vagal vasoconstriction of the coronary arteries, a hypothesis which has been promoted by the fact that this reflex is abolished by the administration of atropine, or section of the vagal nerves. ${ }^{1,9}$ In addition, since 1878, it has been suggested that disease of the biliary tract is far more common in patients who die of ischaemic heart disease..$^{5,9,21,23,25,26}$ At the postmortem of the celebrated John Hunter, who during his lifetime had suffered anginal attacks, a gall bladder packed with stones, and also coronary atherosclerosis, was noted. ${ }^{4}$

With these thoughts in mind, and, too, the consequences which may arise when these patients undergo anaesthesia, we have undertaken a survey of 968 patients in the Kingston General Hospital with gall-bladder disease during the five years from 1957 to 1961 inclusive; and have investigated their relationship to any associated heart disease.

\section{GaLtL BLADDER Disease}

In thıs paper, gall bladder disease is classified as:

1. Acute cholecystitis, with or without cholelithiasis.

2. Chronic cholecystitis.

3. Chronic cholecystitis with cholelithiasis.

The first group is considered important, whether associated with stones or not, for as an entity it so often simulates ischaemic heart disease. The second group includes the debated entity of subacute cholecystitis. In the third group, we have considered that all patients with cholelithiasis have an associated cholecystitis, an academic point which is, as yet, still debațed.

\section{Heart Disease}

In order to enumerate the associated heart disease in these patients, we have classified those with cardiac pathology as follows:

1. Congenital.

2. Acquired:

(i) Ischaemic heart disease.

(ii) Hypertension and/or hypertensive heart disease.

(iii) Ischaemic heart disease with hypertension and/or hypertensive heart disease.

'Department of Anaesthesia, Queen's University, and the Kingston General Hospital, Kingston, Ontario. 
(iv) Valvular heart disease.

(v) Arrythmias and heart blocks.

The following points are made to give our standards and reasons for classification of heart disease in this manner.

\section{Congenital}

Congenital heart disease has been left as an entity, without further subclassification, as we felt that nothing would be gained in relation to gall bladder disease by so doing.

\section{Acquired}

(i) Ischaemic heart disease. This subclassification of acquired heart disease has been defined by the late Dr. Paul Wood ${ }^{26}$ as "occlusive disease of the coronary arteries of sufficient degree to prevent the coronary circulation meeting the metabolic demands of the heart." It encompasses many separate pathological processes, all of which, however, lead to a similar clinical picture. Any variation from this pattern may lead to a vast differential group of diagnoses, not the least of which is that of gall bladder disease. ${ }^{71 t}$

To be included in this group, a patient must have had a suggestive history with: (a) E.C.G. evidence; or $(b)$ X-ray evidence of calcification of the aorta and/or valves; or $(c)$ post-mortem evidence.

(ii) Hypertension and hypertensive heart disease. A hypertensive patient has been taken to be one with a consistent blood pressure of $150 \mathrm{~mm}$. $\mathrm{Hg}$ systolic over $90 \mathrm{~mm}$. Hg diastolic, if under 50 years of age. If over this age, the limit has been raised to $165 \mathrm{~mm}$. $\mathrm{Hg}$ systolic over $95 \mathrm{~mm}$. $\mathrm{Hg}$ diastolic. ${ }^{9}$ Hypertensive heart disease has been included in this group, as nothing would be gained in this survey by differentiating between them, and the difficulty of knowing precisely when cardiac complications of hypertension develop may be appreciated, particularly as there is no correlation between them and the duration and severity of hypertension. ${ }^{9}$

(iii) Ischaemic and hypertensive heart disease. The inability to separate patients with both these types of heart disease occurring concurrently has led us to include this group as a separate entity. However, in the final figures, we have included these with ischaemic heart disease, as these patients fulfilled the requirements given previously and, as already stated, are of particular interest.

(iv) Valvular heart disease. This group of patients was shown to have definite valvular pathology, without any signs and symptoms which would allow them to be included in any of the other classifications.

(v) Arrythmias and heart blocks. This is a group of patients who have developed arrythmias or heart blocks, without any other apparent heart disease. Whilst the presence of an arrythmia does not necessarily mean that heart disease exists, it has been found more frequently in those with the disease. ${ }^{920} 26$ Heart blocks being conduction abnormalities these have been included as well.

\section{Discussion}

The ratio of males to females with gall bladder disease is, as expected, approximately $1: 3,{ }^{11}: 3$ although Breyfogle $(1940), 5$ in his post-mortem series, 
showed a much lower incidence of females with gall bladder disease. There is relatively little variation in the frequency with which heart disease occurs in either group-51.0 per cent and 49.2 per cent respectively-giving an over-all incidence of 49.7 per cent ( see Table I).

TABLE I

Total Number or Patirnts ayd the Number and Per CrNTage with Associated Heart Disease

\begin{tabular}{lccc} 
& & \\
& No. of cases & No. of cases \\
with heart disease & $\%$ \\
\hline Total & 968 & $4 \% 1$ & 497 \\
Males & 247 & 125 & 510 \\
Females & 723 & 356 & 492 \\
\hline
\end{tabular}

Almost all the patients coming to operation underwent cholecystectamy, with or without further modifications of the operation, for example, lexploration of the common bile duct. In the male group, there was only one biliary tract operation not including cholecystectomy, on a patient with ischaemic heart disease and a past myocardial infarction. In the female group, there were eleven: three without heart disease; four with ischaemic heart disease, of whom two had had previous infarctions; two with hypertension; one with ischaemic heart disease and hypertension; and one with valvular heart disease.

Whilst calculus cholecystitis is far more common in this series than either of the other classifications, there is a remarkably constant figure of approximately 50 per cent of heart disease in each classification of gall bladder disease, both in the totals and in those coming to operation, excepting those females with chronic cholecystitis, who showed an incidence of about 40 per cent in both groups (see Table II). This appears to indicate that the type of gall bladder disease does not influence the incidence of heart disease. Willius and Fitzpatrick $(1925)^{25}$ showed definite cardiovascular system changes in 39 per cent of cases of chronic disease of the gall bladder, whilst Schwartz and Herman (1931) ${ }^{21}$

TABLE II

Classitica tion of Gall Bladder Discase iv the Male and Fevale Grocips. 7he [otals, A \D the Number Lndercoing, Operatiós, and the Associated HEart Dislas i Each OT THLIT

\begin{tabular}{|c|c|c|c|c|c|c|c|c|}
\hline & \multicolumn{4}{|c|}{ Male } & \multicolumn{4}{|c|}{ Female } \\
\hline & No. & With H.D. & $\begin{array}{l}\text { Opera- } \\
\text { tions }\end{array}$ & $\begin{array}{l}\text { With } \\
\text { H.D. }\end{array}$ & No. & $\begin{array}{l}\text { Mith } \\
\text { H.D. }\end{array}$ & $\begin{array}{l}\text { Opera- } \\
\text { tions }\end{array}$ & $\begin{array}{l}\text { With } \\
\text { H.D. }\end{array}$ \\
\hline $\begin{array}{l}\text { Acate } \\
\text { Percentage }\end{array}$ & $\begin{array}{ll}64 & \\
26 & 1\end{array}$ & $\begin{array}{l}34 \\
272\end{array}$ & $\begin{array}{l}23 \\
172\end{array}$ & $\begin{array}{l}11 \\
193\end{array}$ & $\begin{array}{r}149 \\
206\end{array}$ & $\begin{array}{l}78 \\
219\end{array}$ & $\begin{array}{l}5.5 \\
123\end{array}$ & $\begin{array}{ll}30 \\
151\end{array}$ \\
\hline $\begin{array}{l}\text { Chronic } \\
\text { Percentage }\end{array}$ & $\begin{array}{l}4: 3 \\
176\end{array}$ & $\frac{22^{\circ}}{17} 6$ & $\begin{array}{l}18 \\
134\end{array}$ & $\begin{array}{r}7 \\
123\end{array}$ & $\begin{array}{r}121 \\
167\end{array}$ & $\begin{array}{l}46 \\
129\end{array}$ & $\begin{array}{l}54 \\
12.1\end{array}$ & $\begin{array}{r}19 \\
96\end{array}$ \\
\hline $\begin{array}{l}\text { Calculus } \\
\text { cholecistitis } \\
\text { Percentage }\end{array}$ & $\begin{array}{r}138 \\
563\end{array}$ & $\frac{69}{552}$ & $\begin{array}{l}93 \\
094\end{array}$ & $\begin{array}{l}39 \\
684\end{array}$ & $\begin{array}{r}4.53 \\
027\end{array}$ & $\begin{array}{r}232 \\
652\end{array}$ & $\frac{338}{75} 6$ & $\frac{149}{753}$ \\
\hline Total & $.24 j$ & 125 & 134 & 57 & 723 & 356 & 447 & 198 \\
\hline Percentagc tota & 100 & 1000 & 1000 & 1000 & 1000 & 1000 & 1000 & 1000 \\
\hline
\end{tabular}


reported disease of the cardiovascular system in 63 per cent of patients with calculus or non-calculus cholecystitis.

Wood (1961) ${ }^{26}$ stated the incidence of ischaemic heart disease to be 2.0 per cent of the total population, and 30.0 per cent of all clinical cases of heart disease; and that of hypertension to be 3.0 per cent and 25.0 per cent, respectively. Breyfogle (1940), ${ }^{5}$ in a large series of post-mortems, showed an association of gall bladder disease and coronary disease in 21.8 per cent of all the cases; whilst Walsh et al. (1941), ${ }^{22}$ in a similar series, reported an incidence of 27.0 per cent.

TABLE III

Classification or Heart Disease in Both Miale and Female Groups

\begin{tabular}{lrrrr} 
& $\begin{array}{c}\text { Males with } \\
\text { heart disease }\end{array}$ & Percentage & \multicolumn{3}{c}{$\begin{array}{c}\text { Females with } \\
\text { hectrt disease Percentage }\end{array}$} \\
\hline Congenital & 0 & 0 & 2 & 0 \\
Ischaemic & 87 & 69 & 20.5 & 576 \\
Hypertension & 13 & 104 & 70 & 197 \\
Ischaemic and hy pertension & 20 & 160 & 69 & 194 \\
Valvular & 2 & 16 & 5 & 14 \\
Arrythmias and heart blocks & 3 & 24 & 5 & 14 \\
Total & 125 & 1000 & 3561 & 1000 \\
\hline
\end{tabular}

In this series, when those with ischaemic heart disease and hypertension or hypertensive heart disease are included, there is an over-all incidence of ischaemic heart disease of 39.4 per cent-43.6 per cent in the male group and 37.9 per cent in the female group. Of these, 15 of the male and 27 of the female patients had had previous myocardial infarctions, a percentage of the total heart disease, in each group, of 12.0 per cent and 7.6 per cent respectively. These figures are higher than those of the authorities quoted for two possible reasons: (1) there has been a ten-fold increase in coronary heart disease over the past 30 years, ${ }^{17}$ (2) our series includes only those cases of diagniosed gall bladder disease, in hospital.

In addition, these figures show an interesting over-all ratio of ischaemic heart disease of 1.2:1.0, male to female, whereas Wood ${ }^{28}$ gives $4: 1$ as a normal. Thus, there is approximately a three-and-a-half-fold increase in ischaemic heart disease in the female group.

Hypertension and hypertensive heart disease is the only other classification of heart disease of note in this series, being 9 per cent of those with gall bladder disease. The number with this complication, as expected, is almost twice as high in females as in males. ${ }^{9}$

As the incidence of ischaemic heart disease is 79.2 per cent of the total number of cases of associated heart disease- -85.6 per cent of the male and 77.0 per cent of the female, cases-the total incidence of heart disease will very closely reflect that of ischaemic heart disease, in both Figures 1 and 2 (see Table III).

The majority of cases, both the total and those with heart disease, come from the age group between 41 and 80 years, reaching a peak between 61 and 70 


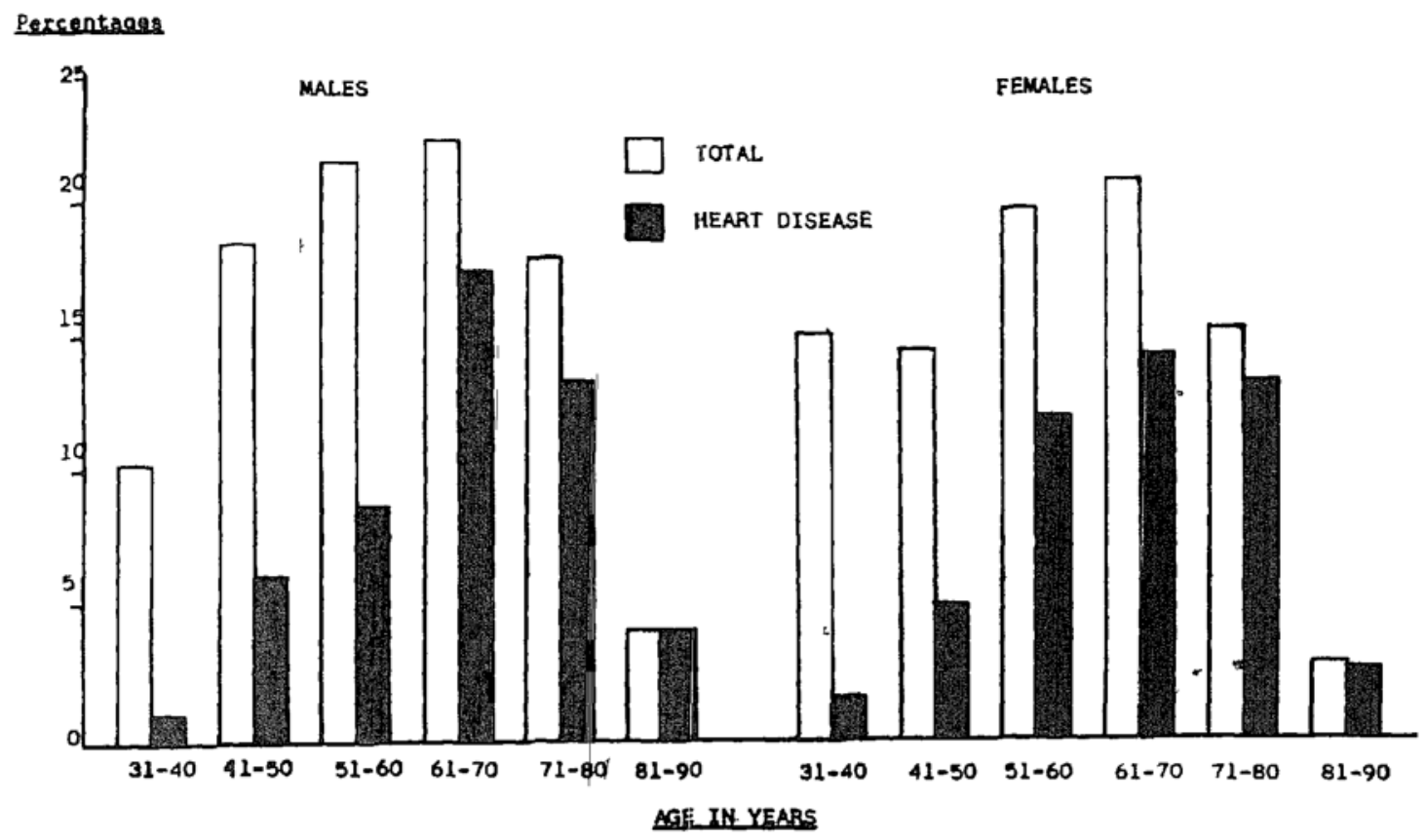

FIGURE 1. Percentages of patients, in decades: total and those with heart disease.

years. Before 31 years and after 90 years, there are no cases of heart disease in the males, and only 0.3 per cent in the females.

The rise in associated heart disease may be appreciated (see Fig. 1). In both groups, from a percentage of about 10 per cent of cardiac involvement in the 31-40 decade, there is a sharp rise to about 33 per cent in the next decade. In males, the percentage involvement, per decade, then rises to 40 per cent, 75 per cent for two decades, and finally 100 per cent. In females, the involvement rises are 60 per cent, 70 per cent, 90 per cent and 95 per cent per decade.

Cassidy $(1946)^{6}$ has shown that whilst 70 per cent of the cases of ischaemic heart disease occur between 50 and 70 years, in men 3.2 per cent occurred between 30 and 40 years and 14.6 per cent between 40 and 50 years. The group of male patients which we surveyed showed an actual incidence of ischaemic heart disease of 4.0 per cent between 31 and 40 years and 20.0 per cent between 41 and 50 years, whilst the female patients had an incidence of 4.5 per cent and 16.2 per cent, respectively.

As we have mentioned previously, it is difficult to assess the increase in these percentages, for the reasons given. However, the increased incidence of ischaemic heart disease in the females has been demonstrated even more forcibly, particylarly as Hedley (1939) ${ }^{12,26}$ gave the normal sex ratio of isschaemic heart disease in those under 50 years of age as 8:1, male to female.

We have already shown that the age groups of interest in this series are between 41 and 80 years. The over-all percentage of operations is 59.8 per cent; 54.8 per cent of the male group and 61.1 per cent of the female group. The percentages of heart disease in these groups are 43.4 per cent, 41.6 per cent, "and 44.2 per cent respectively. 


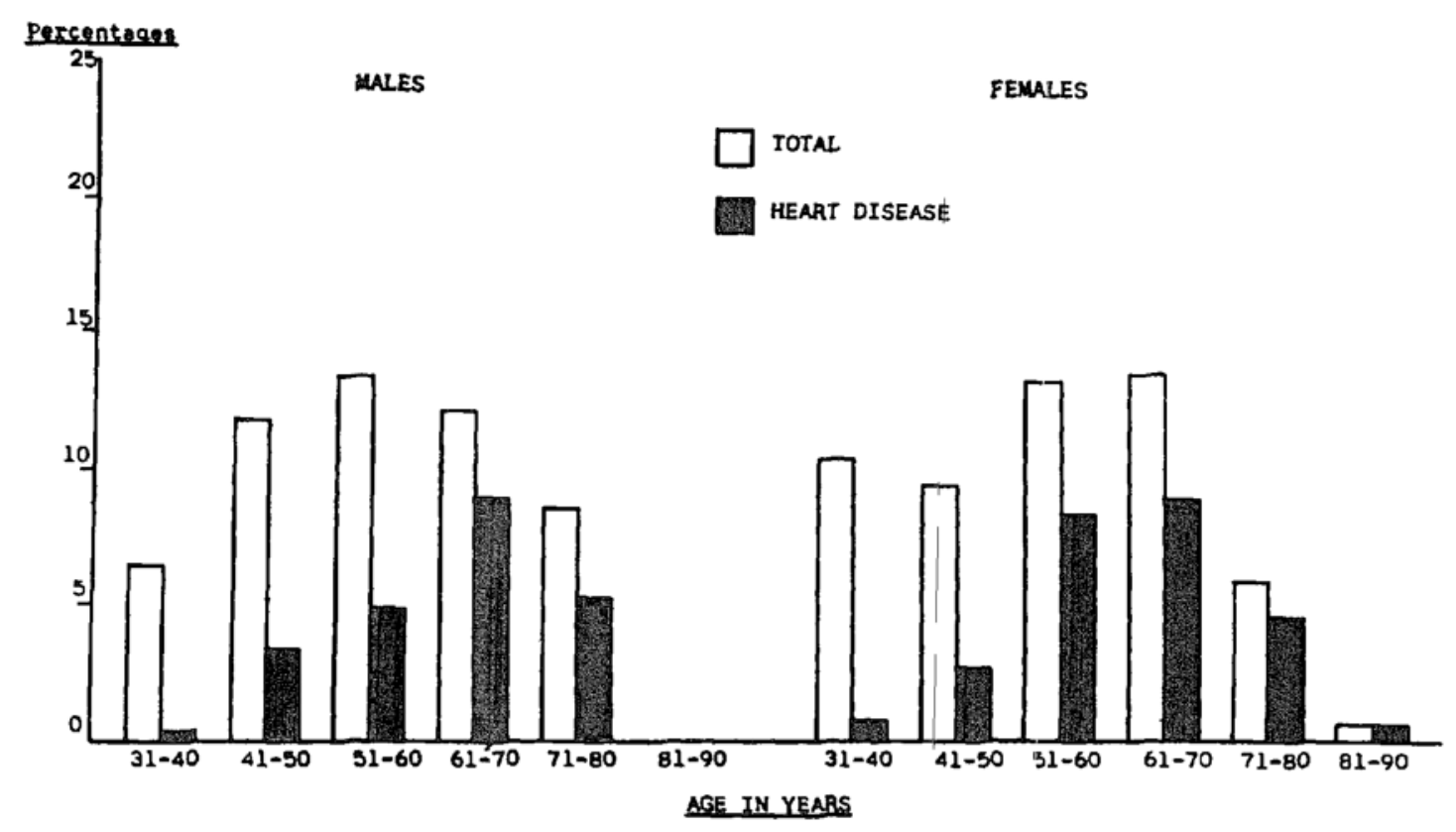

Figure 2. Percentages of patients coming to operation. total and those with heart disease.

Again one may appreciate the rise in cardiac involvement (see Fig. 2). In both groups there is about a 7 per cent involvement in the 31-40 decade. The subsequent percentage rise, per decade, increases in males to 30 per cent, 35 per cent, 75 per cent, and 60 per cent; and in females to 30 per cent, 65 per cent for two decades, 80 per cent and 100 per cent. These figures are very similar to those shown in the previous figure, indicating a similar relative proportion of cardiac involvement, in both the total number of cases and these coming to operation.

Anaesthetic risk increases with age, and even more so with a combination, which our figures show, of increasing age and ineidence of heart disease. However, one must remember that younger people with ischaemic heart disease have a very much higher mortality rate, if infarction is precipitated.9 ${ }^{90}$ They will, therefore, constitute an even graver anaesthetic risk than the aged, when associated with this type of heart disease. These patients all tolerate operation well, provided that nothing is done to precipitate further myocardial ischaemia. ${ }^{2,24,27}$ However, Nachlas et al. (1961.) ${ }^{18}$ have stated that the morbidity and mortality in those with coronary artery disease is 2 to 3 times higher than in those without involvement.

Whilst all patients with gall-bladder disease do not fit into the classical category of "fat, forty, fertile, and flatulent," there can be no doubt that a vast number of these patients are, overweight. Here, therefore, is an added risk to both morbidity and mortality; and the recent interesting statement by Phillips $(1961)^{19}$ that "for every $10 \mathrm{lbs}$. overweight there is an increase above the àverage death rate of about $8 \%$ " is well to bear in mind. Add cardiovascular disease to these patients, and the mortality is more than twice that of those of normal weight, without even their undergoing surgery. 
In unselected patients, postoperative myocardial infarctions have been reported as occurring in from 2.4 per cent, Driscoll et al. $(1961)^{8}$ to 5.6 per cent, Master et al. (1938), ${ }^{15}$ and in those with preoperative E.C.G. abnormalities, Driscoll et al. $(1961)^{8}$ have shown a 7.2 per cent infarction rate. Landelius and Vinnars $(1961)^{13}$ reported, in biliary tract surgery, about 1.4 per cent over-all postoperative mortality, between 1953 and 1957, while Mendelson and Monheit $(1956)^{16}$ showed that there was an 8 per cent incidence of silent infarction, in those with heart disease undergoing similar procedures.

TABLE IV

Diagnosed Postoperative Myocardiat Infarctions

\begin{tabular}{|c|c|c|c|c|}
\hline Age and sex & Preoperative diagnosis & Operation & Postoperative course & Condition \\
\hline 50 y $\mathrm{r}$. & $\begin{array}{l}\text { Acute cholecs stitis } \\
\text { Ischaemic heart } \\
\text { disease }\end{array}$ & $\begin{array}{l}\text { Cholecystectomy \& } \\
\text { appendicectomy }\end{array}$ & $\begin{array}{l}\text { Inferior wall infarc- } \\
\text { tion on } 3 \text { rd day }\end{array}$ & Survived \\
\hline 52 yr. M. & $\begin{array}{l}\text { Calculus cholecy stitis } \\
\text { Ischacmic heart } \\
\text { disease }\end{array}$ & $\begin{array}{c}\text { Cholecystectomy \& } \\
\text { appendicectomy }\end{array}$ & $\begin{array}{l}\text { Anterior wall infarc- } \\
\text { tion on } 2 \text { nd day }\end{array}$ & $\begin{array}{l}\text { Died, on } \\
\text { same day }\end{array}$ \\
\hline $523 \mathrm{r} . \mathrm{M}$. & $\begin{array}{l}\text { Calculus cholecy stitis } \\
\text { lschaemic heart } \\
\text { disease } \\
\text { Hyptertension }\end{array}$ & Cholecistectomy & $\begin{array}{l}\text { Anterior wall infarc- } \\
\text { tion on } 8 \text { th day }\end{array}$ & $\begin{array}{l}\text { Died, on } \\
\text { loth day }\end{array}$ \\
\hline 55 уг. F. & $\begin{array}{l}\text { Calculus cholecy stitis } \\
\text { lschaemic heart } \\
\text { disease } \\
\text { Atrial fibrillation } \\
\text { Hypertension }\end{array}$ & $\begin{array}{l}\text { Cholecy stectomy \& } \\
\text { exploration of } \\
\text { common bile duct }\end{array}$ & $\begin{array}{l}\text { Anterior wall infarc- } \\
\text { tion on } 4 \text { th day }\end{array}$ & Survived \\
\hline 72 yr. F. & $\begin{array}{l}\text { Calculus cholecy stitis } \\
\text { Ischaenic heart } \\
\text { disease } \\
\text { Right-bundle branch } \\
\text { block }\end{array}$ & Cholecystectomy & $\begin{array}{l}\text { Inferior wall infarc- } \\
\text { tion on } 4 \text { th day }\end{array}$ & $\begin{array}{l}\text { Died, on : } \\
\text { 33rd day }\end{array}$ \\
\hline
\end{tabular}

Following operation in this series, there were five diagnosed myocardial infarctions (see Table IV). All had been diagnosed preoperatively as having ischaemic heart disease. This gives an incidence, of approximately 2.0 per cent, in those patients coming to biliary tract surgery with established cardiac pathology. Two of these patients, survived, and three died.

\section{Case Hrstory}

The following case history prompted our investigation, and encompasses many of our illustrated points.

A 37-year-old white male was admitted to the hospital with a diagnosis of possible coronary occlusion. He had a history of severe mid-sternal pain for 12 hours preceding admission, squeezing in character, not radiating, coming on suddenly and gradually subsiding. In addition, he complained of slight shortness of breath on exertion and occasional mild attacks of paroxysmal nocturnal dyspnoed. His past history was not relevant. His only previous admission to hospital had been at the age of 25 years for tonsillectomy, when no abnormalities had been detected. Family history elicited that his father was hypertensive, while his mother suffered from ischaemic heart disease 
and had had a previous myocardial infarction. Examination found him to be obese, weighing $200 \mathrm{lb}$., with a blood pressure of $150 / 96 \mathrm{~mm}$. Hg, in the supine position; but otherwise examination was essentially negative. A diagnosis was made of hypertension and possible coronary insufficiency.

Laboratory investigation showed a haemoglobin of $15.5 \mathrm{gm}$. per $100 \mathrm{ml}$., white cell count of 10,550 per cu. mm., and a sedimentation rate of $30 \mathrm{~mm}$. Urinalysis was normal. Three serial serum glutamic oxalacetic transaminases and electrocardiographic tracings on three successive days were normal, as, too, was that tracing following an exercise test. X-rays showed a normal chest, a normal stomach and duodenum, and a normally functioning gall bladder with multiple radiolucent calculi.

Treatment consisted of a 1200 calorie diet without medication. The patient complained of some heaviness and twinges of chest pain the day following admission, but from then on appeared to have no complaint. Consultations by an internist and a surgeon led to the belief that his signs and symptoms had been caused by his gall bladder disease and he was posted for a cholecystectomy 9 days after admission.

The operation was completed in 1 hour 20 minutes under general anaesthesia, and throughout the procedure his pulse and blood pressure remained constant. Blood loss was estimated at $100 \mathrm{ml}$. He was sent to the recovery room, where it was felt that his ventilation was inadequate, probably because of incomplete reversal of muscle relaxants. He was given a further intravenous injection of atropine, followed by neostigmine. He suffered no depression or abnormality of any sort, being discharged after $2^{1 / 2}$ hours to his room. His condition continued good, but drowsy. He was sufficiently awake to talk sensibly to his wife $2 \frac{1}{2}$ hours after his return. Twenty minutes later he suddenly collapsed, having complained of pain in his chest. His breathing was shallow and he was cyanotic and unresponsive, with no recordable blood pressure or pulse. External cardiac massage, and mouth-to-mouth resuscitation were of no avail, and he was pronounced dead.

At post-mortem it was shown that the patient had suffered from:

1. Generalized arteriosclerosis of the coronary arteries, marked in the left decending and circumflex branches and moderate in the right circumflex.

2. Hypertrophy of the heart, particularly the left ventricle, with fatty degeneration.

3. Two small, old, interventricular septal myocardial infarctions.

4. Fatty degeneration of the liver.

5. Slight nephro-sclerosis.

6. Acute congestion of the lungs, liver, and spleen.

There was no evidence that myocardial infarction had occurred either immediately prior to admission, or prior to death. However, it was felt that coronary occlusion was the cause of his sudden death which, under these circumstances, leaves no time for infarction to be produced (Boyd $(1961)^{4}$ ).

\section{Conclustons}

The conclusions which may be drawn from this five-year survey are:

1. The ratio of male to female patients with gall bladder disease is $1: 3$, as expected.

2. There is an incidence of heart disease of approximately 50 per cent in those with gall bladder disease, which does not vary with the sex.

3. The type of gall bladder disease does not appear to influence the incidence of associated heart disease, which is approximately equal in all groups. 
4. Ischaemic heart disease predominates in those with gall bladder disease, occurring in about 80 per cent of cases with associated heart disease.

5 . With gall bladder disease, there appears to be a higher over-all incidence of ischaemic heart disease than normal.

6. In females of all ages, with gall bladder disease, there is a definite increase in ischaemic heart disease over the normal.

7. The majority of cases of gall bladder disease, and those with associated heart disease, occur between 40 and 80 years, reaching a peak between 60 and 70 years.

8. There is a similar relative proportion of cardiac involvement in the total number of cases of gall bladder disease, and in those coming to operation.

9. The postoperative infarction rate in those undergoing biliary tract surgery with associated heart disease is 2.0 per cent.

\section{RECOMMENDATIONS}

With these facts in mind, we therefore recommend:

1. All patients under forty years of age, with gall bladder disease, should be carefully investigated for evidence of heart disease, particularly if surgery is contemplated and there is anything to suggest that the gall bladder disease is not a clear-cut entity."

2. All patients over forty years of age, with gall bladder disease, should be investigated for evidence of heart disease and should not be operated upon until these investigations have been completed.

3. In view of the high percentage of cardiac involvement found in these patients, every effort should be made to prevent circumstances which may precipitate deleterious effects, during anaesthesia for gall bladder or any other proposed surgery.

4. The overweight patient with gall bladder disease should be made to reduce, whether or not there is evidence of heart disease.

In short, we advocate caution in those with gall bladder disease, particularly if coming to operation, though we would not wish to see the situation arise, which has been so aptly put forward by Bomford (1962) ${ }^{3}$ :

I forsee a gloomy future for that not uncommon object, the middle-aged man with a little hypertension and some evidence of cardiac ischaemia. Clearly his blood pressure must be reduced by hypotensives. Clearly since he is subject to stress, he should be sedated with chemical tranquillisers. Accept the blood fat hypothesis and he should certainly be defatted by a low animal-fat diet. If he has had a small infarct, he must certainly go on long-term anticoagulants. Ischaemic heart disease is far commoner in males than females, so would it not be safer to give him some oestrogens? Indeed, as a measure of mass prophylaxis, would it not be better that the whole middle-aged male population should be permanently tranquillised, hypotensised, defatted, anticoagulated, and emasculated?

\section{SUMMARY}

A five-year survey has been undertaken of patients with gall bladder disease, and their relation to associated heart disease investigated. Partionlar attention 
has been paid to ischaemic heart disease, and the anaesthetic risks involved in these patients discussed. An illustrative case history has been reviewed. From this survey, conclusions have been drawn, and recommendations made.

\section{RÉSUMÉ}

Depuis 1893, on émet des opinions sur une théorie voulant qu'il existe une relation de cause à effet entre les maladies des voies biliaires et l'angine de poitrine $^{1,4,5,9,10,21,22,23,25,26}$ Nous avons fait une étude qui a duré cinq ans sur des porteurs de maladie des voies biliaires et nous avons recherché et étudié la coexistence des troubles cardiaques et des troubles vésiculaires. Plus particulièrement nous avons étudié les ischémies myocardiques et|les risques anesthésiques que deviennent ces malades.

Voici les conclusions à tirer de cette étude qui a duré cinq ans:

1. Comme on s'y attendait, il y a 3 femmes contre 1 homme qui souffrent de la vésicule.

2. Chez les porteurs de troubles vésiculaires, 50 pour cent sont atteints du coeur, pourcentage qui demeure le même dans les deux sexes.

3. La variété des troubles vésiculaires ne semble pas influencer la fréquence des troubles cardiaques; elle est à très peu près la même dans tous les groupes.

4. Les troubles ischémiques ont la vedette chez les porteurs de maladies vésiculaires; il comptent pour 80 pour cent des cas porteurs de troubles cardiaques.

5. Chez les vésiculaires, la fréquence des troubles ischémiques est plus grande que chez les gens normaux.

6. Chez les porteuses de troubles vésiculaires, quel que soit leur âge, la fréquence des troubles ischémiques est, de façon dẹ́finitive, plus grande que chez les personnes normales.

7. C'est entre 40 et 80 ans, avec un maximum entre 60 et 70 ans, que se manifestent la plupart des maladies vésiculaires, de même que celles qui s'accompagnent de troubles cardiaques.

8. Il existe une proportion relative semblable entre les troubles cardiaques et le nombre total des cas de vésicule et les candidats aux opérations.

9. Le taux des infarctus postopératoires chez les opérés des voies biliaires, porteurs de troubles cardiaques, est de 2.0 pour cent.

\section{Conseils}

N'oubliant pas ces faits, voici nos conseils:

1. Tous les malades n'ayant pas atteint l'âge de 40 ans et souffrant de la vésicule, doivent faire l'objet d'examens spéciaux pour dépister les maladies cardiaques surtout si l'on doit les opérer et si l'on trouve que le syndrome vésiculaire n'est pas classique.

2. Tous les porteurs de troubles vésiculaires, âgés de plus de 40 ans doivent faire l'objet de recherches de troubles cardiaques et ne pas être opérés avant la fin des recherches.

3. Etant donné le pourčentage élevé des troubles cardiaques observés chez 
ces malades, il faut tout mettre $_{\mathfrak{s}}$ en cuvre pour éviter les situations qui pour raient avoir des effets désastreux au cours de l'anesthésie pour la chirurgiè biliaire ou autré.

4. Qu'il soit porteur ou non de troubles cardiaques, l'obèse souffrant de la vésicule doit maigrir.

En somme, nous conseillons de la prudence chez les porteurs de troubles vésiculaires, spécialement s'ils doivent être opérés, bien que nous ne voyionis pas la situation aussi tragique que celle décrite par Bomford (1962)3

Je prévois un avenir sombre pour ce syndrome fréquent: l'homme d'âge moyen, un peu hypertendu et montrant des signes d'ischémie cardiaque.' De toute évidence, il fuut recourir aüx hypotenseurs pour abaisser sa pression; puisqu'il subit une agression, il faut recourir à des tranquilisants chimiques pour le calmer. Si l'on croit à ll'hypothèse des lipides du sang, il faudra les réduire en soumettant le malade à une diète pauvre en graisses animales. Si le rnalade a fait un infarctus, il faut le traiter durant longtemps avec des anticoagulants. Les troubles ischémiques du myocardesont beaucoup plus fréquents chez les hommes que chez les femmes; donc, ne serait-il pas plus prudent de lui donner des oestrogènes? En conséquence, en guise de mesure prophylactique générale ne serait-il pas préférable que toute la population masculine d'âge moyen soit, de façon permanente, tranquilisée, hypotendue, dégraissée, soumise aux anticoagulants et émasculée?

\section{REHERENCES}

1. Avery Jones, F. \& Gunmer, J. W. Pr. Clinical Gastroenterology. Ist ed. Springfield, Ill.' Charles C. Thomas (1960).

2. Beliet, S. Preoperative Preparation of the Patient with Coronary Artery Disease Anesthesiology 17: 391 (1956).

3. Bomford, R. Discussion on the Medical Check-Up or Presymptomatic Diagnosis. Section of General Practice of the Royal Society of Medicine, December 19, 1962. The Practitioner 190: 256 (1963).

4. Boyd, W. Testbook of Pathology. 7th ed. Philadelphia: Lea and Febiger (1961).

5. Breyfogle, H. S. The Frequency of Coexisting Gallbladder and Coronary Artery Disease. J.A.M.A. 114, 1434 (1940).

6. CAssidy, M. Coronary Disease. Lancet ii: 587 (1946).

7. Douthwajte, A. H. Pitfalls in Medicine. Brit. Med. J. 2: 958 (1956).

8. Driscolit, A. C; Hobika, J. H.; Etsten, B. E.; \& Proger, S. Clinically Unrecognized Myocardial Infarction Following Surgery. New Engl. J. Med., 26: 633 (1961).

9. Frienberg, C. K. Diseases of the Heart. 2nd ed. Philadelphia: W. B. Saunders Company (1960).

10. Guéneau de Mussy. Quoted by Revilont. Gaz. d. Hop., p. 666 (1878). As quoted by Breyfogle, Ref. 5 .

11. Harrison, T. R. et al. Principles of Intemal Medicine. 4th ed. New York: McGraw-Hill Book Company, Inc. (1962).

12. Hejley, O. F. Analysis of 5,116 Deaths Reported as Due to Coronary Occlusion in Philadelphia, 1933-7. Public Health Report, Washington, p. 972 (1939). As quoted by Woon, Ref. 26.

13. Landelius, E. \& Vinnars, E. Postoperative Mortality in Relation to Anaesthesia and After Care. Acta Anaesth. Scandinav. 5: 141 (1961).

14. Lonhan, P. H. \& Mossen, D. G. Heart Disease, Anesthesia and Surgery. Anesth. \& Analg. 25: 256 (1946).

15. Master, A. M.; Dack, S.; \& JAFFe, H. L. Postoperative Coronary Artery Occlusion. J.A.M.A. 110: 1415 (19:38).

16. Mendelson, D. \& Monheit, R. S. Electrocardiographic and Blood Pressure Changes during and Following Biliary Tract Surgery. Proc. World Congress of Anesthesiologists, p. 52 (1956).

17. Middleton, H. G. \& Rendell-Baker, L. Anaesthesia, and Coronary Artery Disease. Anaèsthesia 15: $310(1960)$. 
18. Nachlas, M. M.; Abrams, S. J.; \& Golberg, M. M. The Influence of Arteriosclerotic Heart Disease on Surgical Risk. Am. J. Surg. 101: 447 (1961).

19. Prullips, W. The Problem of Obesity. The Practitioner 187: 141 (1961).

20. Rusmeren, R. F. Cardiovascular Dynamics, 2nd ed. Philadelphia: W. B. Saunders Company (1961).

21. Schwartz, M. \& Herman, A. Association of Cholecystitis with Cardiac Affections: Study Based on 109 Cases. Ann. Int. Med. 4: 783 (1931).

22. Walsh, B. J.; Brand, E. F.; Taquin, A. C.; \& White, P. D. The Association of Gallbladder Disease and of Peptic Ulcer with Coronary Disease-A Postmortem Study. Am. Heart J. 21: 689 (1941).

23. Walters, W. \& SNeli, A. Diseases of the Gallbladder and Bile Ducts. 1st ed. Philadelphia: W. B. Saunders Company (1940).

24. Weiss, M. M. SR. \& WeIss, M. M. JR. Risk of Major Surgery in Patients with Old Myocardial Infarction. Surgery 46: 1094 (1959).

25. Wirlius, F. A. \& FitzPataicK, J. M. Relationship of Chronic Infection of the Gallbladder to Disease of the Cardiovascular System. J. Iowa Med. Soc. 15: 589 (1925).

26. Woon, P. Diseases of the Heart and Circulation. 2nd ed. London: Eyre and Spottiswoode (1961).

27. WyLne, W. D. \& Churchll-Davimson, H. C. A Practice of Anaesthesia. Ist ed. Chicago: Year Book Medical Publishers Inc. (1962). 